\title{
REPRESENTAÇÕES SOCIAIS DA CURA DIVINA NO CONTEXTO NEOPENTECOSTAL
}

\author{
SOCIAL REPRESENTATIONS OF DIVINE HEALING ON THE NEOPENTECOSTAL CONTEXT \\ REPRESENTACIONES SOCIALES DE LA CURA DIVINA EN EL CONTEXTO NEOPENTECOSTAL
}

\author{
Ana Paula Hermoso Lopes* \\ Bruna Suruagy do Amaral Dantas ${ }^{* *}$
}

\begin{abstract}
RESUMO
Considerando o crescimento vertiginoso do neopentecostalismo no Brasil nas últimas décadas e seu consequente impacto sociocultural, este estudo buscou investigar os bens simbólicos produzidos no contexto religioso com base na análise das representaçóes sociais da doença e da cura divina, compartilhadas por membros da Igreja Universal do Reino de Deus (IURD). Foram realizadas cinco entrevistas semidirigidas com membros da IURD que relataram ter vivenciado a cura divina. A análise, desenvolvida mediante a utilização do método da hermenêutica de profundidade, revelou a presença de princípios da teologia da prosperidade permeando as representaçóes sociais de cura bem como diferenças importantes entre o discurso oficial da igreja e o reproduzido pelos fiéis. Essa pesquisa evidencia a complexidade e as contradiçōes que caracterizam o processo da cura divina, o que justifica a necessidade de realização de novos estudos nesse campo.
\end{abstract}

Palavras-chave: Cura divina. Representações sociais. Neopentecostalismo. Igreja Universal do Reino de Deus. Hermenêutica de profundidade.

\begin{abstract}
In the light of the rapid growth of neo-Pentecostalism in Brazil in recent decades and its consequent social-cultural impact, the present study sought to investigate relevant aspects of the symbolic effects brought about in a religious context by investigating the social representations of disease and divine healing shared by members of the Universal Church of the Kingdom of God (UCKG). Five UCKG members who reported divine healing experiences were interviewed. The analysis used the methodology of depth hermeneutics and revealed the presence of elements of prosperity theology throughout the social representations of healing, as well as a significant difference between official church discourse and the one portrayed by the churchgoers. This research shows the complexity and contradictions present

Texto recebido em 10 de março de 2014 e aprovado para publicação em $1^{\circ}$ de julho de 2015.

- Graduanda de Psicologia na Universidade Presbiteriana Mackenzie, São Paulo-SP. E-mail: aphermoso@yahoo.com.br.

* Doutora em Psicologia Social pela Pontifícia Universidade Católica de São Paulo e professora da Faculdade de Psicologia da Universidade Presbiteriana Mackenzie.E-mail: brunasuruagy@gmail.com.
\end{abstract}


in the divine healing process, justifying the need for further studies in this field.

Keywords: Divine healing. Social representations. Neo-Pentecostalism. Universal Church of the Kingdom of God. Depth hermeneutics.

\section{RESUMEN}

Teniendo en cuenta el rápido crecimiento del neopentecostalismo en Brasil en las últimas décadas y su consiguiente impacto sociocultural, este estudio buscó investigar los aspectos relevantes de los bienes simbólicos producidos en el contexto religioso basándose en el análisis de las representaciones sociales de la enfermedad y la curación divina, compartidas por los miembros de la Iglesia Universal del Reino de Dios (IURD). Se realizaron cinco entrevistas semidirigidas con miembros de la IURD que relataron haber vivido la experiencia de curación divina. El análisis realizado con la utilización del método de la hermenéutica de profundidad reveló la presencia de los principios de la teología de la prosperidad que impregnan las representaciones sociales de curación, así como diferencias importantes entre el discurso de la iglesia oficial y el reproducido por los fieles. Esta investigación evidencia la complejidad y las contradicciones que caracterizan el proceso de curación divina, lo que justifica la necesidad de realizar nuevos estudios en este campo.

Palabras clave: Curación divina. Representaciones sociales. Neopentecostalismo. Iglesia Universal del Reino de Dios. Hermenéutica de profundidad.

\section{INTRODUÇÃO}

D e acordo com Mariano (2010), a partir da década de 1940, houve uma grande expansão do evangelismo da cura divina nos países ocidentais. Esse tipo específico de pentecostalismo, que surgiu no Brasil na década de 1960, recebeu várias denominações dos pesquisadores, entre elas "neopentecostalismo". Tal movimento se apropriou de alguns elementos do pentecostalismo tradicional, como a cura divina (Oro, 2001). No Brasil, tem havido um aumento considerável do número e da variedade de igrejas neopentecostais que prometem cura para alcoolismo, depressão, drogadição e doenças psiquiátricas. Atualmente, as igrejas que mais exploram essa temática a fim de alcançar novos adeptos são a Igreja Universal do Reino de Deus (IURD), cujo líder é o bispo Edir Macedo, e a Igreja Mundial do Poder de Deus, fundada e dirigida pelo apóstolo Valdemiro Santiago. 
Embora o movimento neopentecostal seja fragmentado e não apresente uma unidade teológica, a maioria dos pregadores propóe banir a doença (Romeiro, 2007). Triunfalismo é o nome que se dá à tese de que o convertido deve ter sucesso em todas as áreas da vida, o que inclui a saúde física e mental. A teologia da prosperidade, característica das igrejas neopentecostais, é um sistema de crenças que estabelece uma relação direta entre a cura e a fé. Nesse contexto religioso, a saúde física e a mental fazem parte da almejada prosperidade e estão, portanto, relacionadas à bênção divina, assim como a falta de saúde e a ausência da "cura" são resultados da falta da bênção ou da ausência da fé. Muitas vezes, estabelece-se um ciclo que se retroalimenta, seja para criar esperança de cura, seja para aumentar a culpabilização ou minimizar a frustração quando a cura não vem.

A igreja neopentecostal também oferece ao doente uma ressignificação da doença a partir do referencial da luta entre o bem e o mal, o que pode gerar efeitos discrepantes: por um lado, proporciona alívio e esperança, já que a mesma instituição que demoniza a doença, expulsa o demônio e produz a sensação de controle para o sujeito que realiza as práticas instituídas pela igreja. Por outro lado, culpabilizar os demônios por todos os males costuma causar ainda mais sofrimento, ansiedade e culpa para o fiel que encara a doença como consequência da falta de fé.

É preciso lembrar que a doença também envolve fatores econômicos e sociais. A maioria dos membros das igrejas neopentecostais são moradores da periferia das grandes cidades, que não recebem proteção social e assistência sanitária, inseridos em um sistema de saúde precário, os quais precisam encontrar soluções acessíveis. Nesse cenário de escassez e vulnerabilidade, a mensagem eclesiástica se mostra atraente e oportuna ("pare de sofrer"), e aparece como uma alternativa barata, acessível e rápida de "tratamento" para problemas emocionais, psiquiátricos, financeiros, de dependência química e de relacionamento conjugal. As igrejas se apresentam como um pronto-socorro espiritual, aberto 24 horas para atender pessoas que enfrentam os mais graves tipos de infortúnios, com promessas de solução para todos eles. Por meio de uma ressignificação do mundo em termos da eterna guerra espiritual entre o bem e o mal, produz-se um processo de alienação das perversas estruturas sociais que excluem muitos indivíduos do sistema público de saúde (Bittencourt Filho, 1994).

Considerando-se a escassez de trabalhos acadêmicos abordando a questão da cura divina no neopentecostalismo, é de extrema importância que a Psicologia social lance seu olhar nessa direção, na tentativa de compreender mais profundamente como esse fenômeno se articula no âmbito social e individual, apreendendo, assim, de que modo os elementos sociais são assimilados por 
cada indivíduo. Tendo em vista o crescimento e a importância dos movimentos neopentecostais na cultura brasileira, esta pesquisa investigou os bens simbólicos produzidos no campo religioso com base na análise das representações sociais da cura divina no contexto da IURD.

\section{REFERENCIAL TEÓRICO}

O conceito de representação social foi introduzido por Serge Moscovici, em seu texto de 1961, La psychanalyse: son image et son public. $\mathrm{O}$ autor define representações sociais como

\footnotetext{
Um sistema de valores, ideias e práticas, com uma dupla função: primeiro, estabelecer uma ordem que possibilitará às pessoas orientar-se em seu mundo material e social e controlá-lo; e, em segundo lugar, possibilitar que a comunicação seja possível entre os membros de uma comunidade, fornecendo-lhes um código para nomear e classificar, sem ambiguidade, os vários aspectos de seu mundo e da sua história individual e social (Moscovici, 2003, p. 21).
}

Moscovici parte do conceito de representações coletivas, elaborado por Émile Durkheim, mas sugere que as representações sociais são mais eficientes para abarcar a complexidade e a mutabilidade dos fenômenos do mundo contemporâneo. Durkheim debruçou-se sobre realidades já sedimentadas no decorrer de um longo processo histórico, enquanto que os acontecimentos atuais precisam ser observados sob uma nova perspectiva que considere a grande velocidade com que as pessoas interagem, as informações circulam e os objetos se transformam (Sá, 1995).

Segundo Moscovici (2003), existem dois tipos de conhecimento: aqueles pertencentes aos universos consensuais e aqueles típicos dos universos reificados. Nestes últimos, situam-se as ciências e o pensamento erudito, enquanto que, nos universos consensuais, são produzidas as representações sociais e suas teorias do senso comum. As representações sociais formam-se no cotidiano, articulando informaçōes, ideias, teorias, objetos e práticas, permeados pela experiência pessoal e grupal. Constroem-se no dia a dia, de maneira informal e dialética. Não são impostas pela sociedade ao indivíduo, nem recebidas sem crítica por ele: estão presentes nas relações e são continuamente modificadas pelos sujeitos de acordo com seus valores, julgamentos e vivências particulares.

As representações sociais permitem que diversos assuntos e objetos sejam entrelaçados por meio de uma lógica própria, formando uma teoria ou um conjunto de conceitos (Sá, 1995), construídos tanto pelo indivíduo quanto pelo grupo, num constante intercâmbio de informaçôes e valores. Tais representaçóes 
são coletivas, dado que se constituem na interpessoalidade e na intersubjetividade. São também dinâmicas: o grupo que as construiu não tem controle sobre suas configuraçóes e significados para seus integrantes, outros grupos, ou ainda um membro do grupo, isolado das relações grupais. As representações têm uma característica circulante, móvel e plástica. Depois de criadas, têm caráter autônomo, "Adquirem vida própria, circulam, se encontram, se atraem e se repelem e dão oportunidade ao nascimento de novas representações, enquanto velhas representaçōes morrem" (Moscovici, 2003, p. 41).

As representações sociais se consolidam por meio de dois mecanismos: a ancoragem e a objetivação. A exposição a um conhecimento novo gera certo estranhamento, que provoca incômodo e mal-estar. A fim de compreender e assimilar o novo, o sujeito o compara a conceitos estabelecidos socialmente e, dessa forma, o torna familiar. A ancoragem seria um mecanismo semelhante ao que Piaget propôs a respeito do desenvolvimento infantil, que se dá por meio de esquemas: uma criança que nunca viu um cavalo poderá considerá-lo um "cachorro grande", pois compara o animal desconhecido com o cachorro que lhe é familiar. Ancorar um novo conhecimento, ideia ou objeto é classificá-lo, categorizá-lo dentro de determinados rótulos ou ideias bem conhecidos. Desse modo, uma pessoa que professa certa religião tentará compreender condutas individuais, comportamentos sociais e teorias cotidianas com base em valores religiosos (Moscovici, 2003). Além de categorizado, o novo precisa ser nomeado e, dessa forma, pode ser imaginado e representado.

Para descrever o fenômeno da ancoragem das representações sociais, Moscovici (2003) lança mão da metáfora do bote ancorado em pontos sinalizadores. Nosso espaço social representaria as águas e os pontos sinalizadores os locais seguros, ou seja, aquilo que nos é familiar, conhecido. Algo novo que nos é apresentado seria como um bote perdido, navegando a esmo, sem ter onde ancorar, assim como uma ideia, símbolo e conceito que não tem onde ser categorizado. A nova informação é, então, ancorada no ponto de sinalização mais próximo. Da mesma maneira, o novo é categorizado e incorporado ao sistema de referência existente e dele adquire as mesmas características, estando sujeito aos mesmos julgamentos. Entretanto cabe salientar que a incorporação do novo também pode gerar uma modificação na rede simbólica estabelecida, favorecendo sua adequação e familiarização.

A categorização que ocorre no mecanismo de ancoragem não é neutra: ela determina valores à nova ideia por meio da comparação com paradigmas consolidados. A relação da nova ideia com a ideia conhecida pode ser, portanto, negativa ou positiva. Automaticamente, a nova ideia passa a assumir características aceitáveis ou reprováveis, dependendo de como for classificada. Assim, um novo 
paradigma pode ser mais ou menos aceito de acordo com a sua concordância com paradigmas já existentes. Em outras palavras, é necessário "defini-las como conformes, ou divergentes, da norma" (Moscovici, 2003, p. 65).

O processo de ancoragem não se limita à classificação, mas inclui também a nomeação do novo. Nomear é uma forma de controlar, dominar, possuir aquilo que antes causava incômodo por ser desconhecido. Depois de nomeado, o novo passa a ter seu lugar na matriz de identidade de nossa cultura. Aquilo que pode ser nomeado pode ser comunicado, descrito, distinto de outras coisas. Categorização e nomeação constituem, portanto, o processo de ancoragem das representações sociais e têm como objetivo interpretar características e compreender motivações de pessoas, por exemplo, não servindo apenas para julgar e rotular (Moscovici, 2003).

Por ser compartilhada e reforçada pela tradição, a representação adquire paulatinamente caráter permanente e torna-se tanto mais fossilizada quanto mais se afasta de sua origem. Torna-se realidade social conforme é dada como incontestável e reificada. É nisso que consiste o outro mecanismo das representações, a objetivação, que é a "verdadeira essência da realidade" (Moscovici, 2003, p. 71). Aquilo que era antes visto como novo, abstrato ou distante passa a ser considerado concreto e real. Para que esse processo ocorra, é necessário que a ideia se desprenda de sua materialidade originária e desenvolva a capacidade de ser representada iconicamente.

Objetivar é "descobrir a qualidade icônica de uma ideia ou ser impreciso; é reproduzir um conceito em uma imagem" (Moscovici, 2003, p. 71-72). Comparando-se Deus (que é abstrato) com um pai, temos uma representação icônica de Deus e podemos vê-lo na figura de um homem concreto, cheio de significados e representaçóes. Dessa forma, a ideia (antes abstrata) de um ser invisível e desconhecido pode ser facilmente tida como real ao ser associada com uma representação muito familiar. O núcleo figurativo seria, então, um complexo de imagens que representam uma ideia.

Para Moscovici (2003), existem diferentes níveis de realidade entre a ilusão total e a realidade total. Esses níveis não existem por si, mas devem ser levados em consideração conforme permitem que uma representação se transforme na realidade da representação. Quando uma representação passa a ser o novo paradigma, ela é tão utilizada que elimina a distinção entre imagem e realidade. A imagem deixa de ser um signo e passa a ser a réplica da realidade, abolindo a característica abstrata da representação. Passa, então, a ser representação da realidade, e não mais representação do pensamento. 
Tanto a ancoragem quanto a objetivação estão relacionadas à memória coletiva que, conforme Moscovici (2003), retém os conhecimentos sociais cristalizados, favorecendo a incorporação e familiarização de novos saberes. As ideias, após o processo de objetivação, são sedimentadas e depositadas na memória coletiva, sendo utilizadas no processo de ancoragem, responsável pela assimilação de novos conceitos. Os sentidos acumulados na memória e consolidados no passado histórico são preservados pela experiência subjetiva e pelas práticas culturais, servindo de suporte para o surgimento de novos sentidos.

Segundo Bosi (2003), a memória social não é um fenômeno estático, mas um sistema dinâmico que está em constante processo de transformação, não sendo um mero repositório de lembranças, mas uma forma organizadora. Por isso "é importante respeitar os caminhos que os recordadores vão abrindo na sua evocação, porque são o mapa afetivo da sua experiência e da experiência do seu grupo [...]" (Bosi, 2003, p. 56). O relato de experiências vividas revela as representaçóes sociais organizadas por meio do discurso e da memória.

Desse modo, pode-se asseverar:

Quanto mais o pesquisador entra em contato com o contexto histórico preciso onde viveram os seus depoentes, cotejando e cruzando informaçôes e lembranças de várias pessoas, mais vai se configurando a seus olhos a imagem do campo de significações já pré-formada nos depoimentos (Bosi, 2003, p. 56).

A entrevista semidirigida é um instrumento fundamental para que seja possível entrar em contato com as representações tanto individuais quanto institucionais. Bosi (2003) alerta que os discursos individuais podem muitas vezes estar carregados de estereótipos institucionais, não devendo por isso ser considerados mais "puros" ou autênticos que o discurso oficial. Isso acontece pela própria dimensão dialética das representações sociais, que transitam entre o indivíduo e a sociedade, reinventando-se, transformando-se e atualizando-se indefinidamente. Muitas vezes a memória coletiva se impõe sobre a memória individual, apresentando elementos simbólicos característicos do discurso oficial, com certa impessoalidade, configurando de maneira quase idêntica o discurso de diferentes indivíduos.

Segundo Bosi (2003), "Parece que há sempre uma narrativa coletiva privilegiada no interior de um mito ou de uma ideologia. E essa narrativa explicadora e legitimadora serve ao poder que a transmite e difunde" (p. 18). Tal memória coletiva é produzida "no interior de uma classe, mas com poder de difusão, que se alimenta de imagens, sentimentos, ideias e valores que 
dão identidade àquela classe" (Bosi, 2003, p. 18). Logo, a narrativa coletiva, repleta de significantes e significados, encerra diversas representaçôes sociais que circulam em determinado grupo e são internalizadas por cada indivíduo de modo idiossincrático, preservando, no entanto, seus traços simbólicos primordiais.

\section{METODOLOGIA}

A pesquisa foi desenvolvida com base nos pressupostos fundamentais da investigação participativa, que se caracteriza pelo envolvimento entre pesquisadores e pesquisados durante a realização do trabalho científico (Gil, 1999). Inicialmente, a pesquisa de campo consistiu em visitas periódicas à igreja nos horários dos cultos, sessões de descarrego e reuniōes de libertação, ocasiōes em que se costuma abordar a questão da cura divina, possibilitando, desse modo, uma familiaridade com o universo dos fiéis que frequentam a igreja regularmente assim como uma aproximação do fenômeno das representações sociais ali compartilhadas.

A análise das representaçôes sociais foi realizada segundo a metodologia da hermenêutica de profundidade (HP), que compreende três fases: a análise sóciohistórica, a análise discursiva e a interpretação/reinterpretação. A análise sóciohistórica considera que as formas simbólicas são produzidas e recebidas em um contexto social e um período histórico específicos. Esse contexto sócio-histórico pôde ser analisado por meio de pesquisa bibliográfica. A análise discursiva debruça-se sobre os discursos simbólicos concebidos como estruturas que representam algo, o que deve sempre ser realizado à luz da análise sócio-histórica para que não se torne um fim em si mesmo. Finalmente, a interpretação/ reinterpretação é a síntese, à qual se chega pela articulação das duas primeiras etapas. Nessa terceira fase, procura-se reinterpretar um campo pré-interpretado, levando-se em consideração as possíveis dissonâncias resultantes desse processo interpretativo. Ao interpretar uma forma simbólica por meio da HP, costuma-se surgir um campo de interpretações conflitantes (a interpretação dada a priori pelos sujeitos pertencentes àquele mundo sócio-histórico versus a interpretação que resulta da análise da forma simbólica após a pesquisa).

O referencial metodológico da HP permite que as formas simbólicas sejam "analisadas sistemática e apropriadamente, isto é, de uma maneira que faça justiça ao seu caráter de construtos situados social e historicamente, que apresentam uma estrutura articulada por meio da qual algo é representado ou dito" (Thompson, 2000, p. 377). Nessa perspectiva, a análise das formas simbólicas pode lançar mão de recursos como a análise formal, estatística e objetiva sem, no entanto, desconsiderar a dimensão qualitativa que as caracteriza, compreendendo a 
pesquisa qualitativa e quantitativa como processos complementares e não excludentes.

Tendo em vista a complexidade da temática e a escassez de investigações empreendidas nesse campo, inicialmente realizou-se uma pesquisa exploratória para coleta de dados por meio da aplicação de questionários, de modo a compreender alguns sentidos da cura atribuídos pelos membros da IURD. Foi adotada uma amostra aleatória composta de 31 membros iurdianos, convidados a participar do trabalho em diferentes templos e reuniōes. Os dados quantitativos serviram à confecção de um roteiro, utilizado na condução das entrevistas semiestruturadas, cujo conteúdo foi submetido à análise aprofundada e interpretativa das representações sociais. Cinco membros da IURD, todos do sexo feminino, colaboraram com a pesquisa empírica e concederam seus depoimentos acerca da experiência da cura divina, o que assegurou a compreensão da complexidade desse fenômeno. Para localizar os sujeitos com perfil adequado ao trabalho, adotou-se como procedimento a divulgação da pesquisa nas redes sociais, além da busca (entre conhecidos) de indicações de membros da Universal que tivessem vivenciado a cura divina. Os primeiros contatos foram feitos por telefone, e as entrevistas marcadas conforme a disponibilidade das colaboradoras, ${ }^{1}$ procurando-se tomar precauçôes quanto ao local escolhido, para minimizar os ruídos e as interrupções durante a realização das entrevistas. Cabe salientar que todas as entrevistas foram gravadas para garantir a fidedignidade do material coletado e, na sequência, transcritas ipsis litteris para a análise dos conteúdos dos discursos.

A primeira entrevistada foi Cândida, ${ }^{2} 48$ anos, frequentadora da IURD havia 16, separada, mãe de dois filhos e empregada doméstica, em cujo relato enfatiza que foi curada de 24 bicos de papagaio na coluna. A segunda entrevistada foi Vitória, estudante universitária de 45 anos, 14 deles na Igreja Universal, casada e com uma filha, cujo discurso destaca uma vasta experiência de cura: fibromialgia, lesão no tendão do pé e problema de coluna. Também contou curas divinas recebidas por outros membros da família. Em seguida, foi colhido o depoimento de Lúcia, aproximadamente 70 anos, membro da Universal havia 26 anos, viúva, com duas filhas e dois netos, dona de casa, cuja cura divina incidiu sobre um problema no joelho que a impedia de andar. A quarta colaboradora foi Joana, divorciada, mãe de dois filhos, 45 anos, 20 anos vivendo como fiel iurdiana, dona de casa, que narrou suas várias curas: câncer de mama, leucemia, hemorragias, infecções de urina, infecção generalizada por bactérias e choque anafilático.

\footnotetext{
Participaram da pesquisa qualitativa apenas mulheres, por isso todas as futuras menções a elas serão feitas no gênero feminino. Todos os nomes foram alterados para preservar a identidade das participantes, que receberam carta de informação ao sujeito da pesquisa e assinaram termos de consentimento, autorizando o uso dos dados apenas para fins acadêmicos. As entrevistas foram realizadas entre 4 de março e 16 de junho de 2013, nas cidades de São Paulo, Cotia e Bauru.
} 
Finalmente, a última entrevistada foi Simone, 25 anos, havia 8 anos na igreja, divorciada, a qual sofria de uma gastrite nervosa crônica que lhe provocava desmaios em razão da dor.

A metodologia, seus instrumentos específicos e a amostragem foram definidos com base no pressuposto teórico de que cada indivíduo carrega em si aspectos da comunidade à qual pertence e, por isso, é representante dela, não sendo necessária uma amostra volumosa para se apreender os sistemas simbólicos da totalidade social. O critério para término da etapa de realização das entrevistas foi a repetição dos discursos das participantes ao longo do processo de coleta dos dados, como um indicador de que os elementos simbólicos das representações sociais já haviam sido suficientemente apreendidos pela pesquisa.

A análise dos discursos coletados foi realizada por meio de leitura exaustiva das transcrições, o que permitiu identificar representações semelhantes e dissonantes. Em seguida, foram criadas categorias de agrupamento de tais representaçôes, por exemplo, uma categoria relativa ao dízimo, outra aos mecanismos de fé que determinam a cura divina e ainda às representaçôes da doença. Tais categorias foram examinadas separadamente e, em seguida, articuladas a partir de uma síntese, o que possibilitou verificar como elas estão relacionadas entre si e construir um conhecimento integrado do fenômeno.

\section{ANÁLISE DOS DADOS}

\subsection{Representações sociais da doença e teologia da prosperidade}

Ao ingressar na IURD e tornar-se parte dela, o sujeito apreende um sistema de representaçôes sociais, reinterpretando e ressignificando toda sua existência. Em seu discurso, estabelece uma fronteira nítida entre o período anterior e o posterior à sua inserção na igreja, passando a considerar sua vida negativa na fase em que não frequentava a Universal e a compreendê-la numa perspectiva totalmente positiva após sua adesão aos códigos iurdianos. Enquanto o fiel estiver na igreja e seguir as orientaçooes institucionais, não lhe é imputada qualquer culpa ou responsabilidade pela existência da própria doença, mas o cenário muda quando se rompe com a instituição e se afasta dela, o que pode ser percebido nas declaraçōes de Vitória:

Às vezes você pode ter esse afastamento, [e] você está abrindo brechas [para o inimigo] [...]; as coisas meio que acontecem quando eu dou uma fugida de Deus, [...] eu sinto que não é Ele que me deixou, eu deixei Ele, meio que ele tá assim: lavou as mãos. [...] Esse é o único caminho, se eu sair, o negócio fica muito feio. 
As representações sociais da doença, presentes nos depoimentos das entrevistadas, resultam da articulação entre os sistemas simbólicos iurdianos e as representações estabelecidas, provenientes das igrejas frequentadas anteriormente. Nesse processo de acomodação, as antigas representações modificam-se para acolher as novas ideias que a igreja oferece e, de igual modo, os novos sentidos se alteram para serem acolhidos, adaptando-se à rede de referência existente (Moscovici, 2003). As igrejas anteriores são representadas como instituições "mortas", "paradas" e indiferentes, que não "tocavam" os seus corações nem geravam transformações significativas. Por outro lado, acredita-se que, ao conhecer a Universal e seguir seus rituais, a vida do fiel melhora expressivamente, tanto no âmbito financeiro e profissional quanto no amoroso e emocional.

Apesar dessa comemorada prosperidade, os discursos de modo geral não apontam para a redução da quantidade de doenças após o ingresso na igreja, como se poderia supor com base na teologia da prosperidade, que apregoa a saúde física, emocional e espiritual como indicativo da fé do cristão (Romeiro, 2007). Em vez disso, os relatos revelam que as doenças surgiam enquanto (e porque) as cristãs se envolviam com os trabalhos da igreja e mostravam-se engajadas no proselitismo religioso. A prosperidade, sob o ponto de vista das colaboradoras, parece não estar relacionada à ausência de doenças, mas às vitórias da fé, que se manifestam na cura divina. A diferença não é, portanto, a quantidade ou qualidade das enfermidades antes e depois da IURD, mas o significado que elas assumem e a postura que se adota para lidar com elas.

O bispo Macedo, responsável por assinar a literatura oficial da igreja, é categórico ao ensinar que os demônios são "os causadores de todos os infortúnios que atingem o ser humano, direta ou indiretamente" (Macedo, 2006, p. 93) e, portanto, as doenças seriam indicativos de fraqueza espiritual ou falta de fé do cristão, que se tornou vulnerável aos ataques do mal. As entrevistadas, no entanto, não parecem se sentir responsáveis pelo surgimento de suas doenças. Essas representaçóes da doença que admitem que o fiel possa ficar doente tanto quanto antes de frequentar a Universal (uma prosperidade relativa) são uma adaptação da teologia da prosperidade, num esforço para tornar suportável a frustração de uma vida que não alcança a plenitude física e emocional, justificando, assim, a existência de doenças de uma forma que evita a autoculpabilização.

Nesse processo de acomodação, as ideias novas são relativamente modificadas e adaptadas, sendo, assim, devidamente ancoradas pelos sistemas simbólicos existentes, o que as torna familiares (Moscovici, 2003). Parece que as fiéis dão prioridade à ideia de uma guerra espiritual em que são meras vítimas do mal e, nessas circunstâncias, têm a oportunidade de utilizar a fé, podendo aprimorála, em vez de se perceberem como culpadas pela própria falta de fé, aspecto reforçado pelo discurso institucional. 
As doenças passam a ser entendidas como uma oportunidade de aperfeiçoamento espiritual, seja porque o diabo está atuando por meio da enfermidade e o fiel precisa aprender a lutar contra ele, seja porque são parte de um plano divino de bênçãos futuras, como explica Vitória:

Deus permite que as coisas ruins aconteçam, não só para que a gente veja o poder dele, mas porque ele tem algo melhor pra nos dar, entendeu, lá na frente. Ele tira algo aqui, [...] você questiona o porquê, mas lá na frente ele tem algo assim, mil vezes melhor. Claro, se você ficasse presa naquilo não tomaria posse daquela bênção que tá lá na frente.

As representaçôes da doença como provação divina parecem paradoxais num primeiro momento, se levarmos em conta a premissa de que o fiel deve ser próspero para testemunhar a grandeza de Deus. No discurso de Vitória, o que parece uma contradição, na verdade, corresponde a um pensamento complementar. A doença é compreendida como uma oportunidade para que Deus revele seu poder exatamente quando o fiel decide não a aceitar por meio da "revolta da fé". Primeiro, ela considera: "Como eu vou apresentar minha vida destruída para uma pessoa? [Dirão:] 'Ela serve a Deus e vive doente', 'Ela mora em um lugar ruim', 'A filha é torta', sei lá...”. Em seguida, reflete que “isso é uma provação [por] que nós temos que passar, mas justamente para que Deus mostre que Ele é Deus, entendeu?".

A concepção de que a doença pode ser permitida por Deus não contradiz o que é ensinado na igreja: "quanto às doenças, [...] convém lembrar que elas não são de Deus” (Macedo, 2006, p. 93). A doença é concebida como um ataque do diabo, consentida por Deus, a fim de que a fé do fiel se fortaleça, como explica Joana: "Deus permite que você passe por lutas pra você ter forças, pra que, lá na frente, você não venha a cair, se enfraquecer na fé". Provavelmente, essas representaçooes da doença como provações divinas são provenientes da herança cultural e religiosa da Igreja Católica, predominante no País, e de alguns segmentos evangélicos, que as utilizam para solucionar o problema das patologias que permanecem ou tornam-se mais frequentes mesmo após a conversão.

Além da prosperidade relativa, podemos perceber nas representações sociais da doença uma prosperidade às avessas, a qual justifica doenças que surgem quando o fiel "busca a Deus" intensamente, está "firme na fé" e ativo nos trabalhos da igreja, como verificamos nos depoimentos a seguir:

"A hora que você começa a pegar firme na igreja é a hora que começa a vir as lutas, a vir os problemas. Aí você fala: 'meu Deus, parece que, em vez de melhorar, parece que piora.'” (Joana) 
“Todo mundo tem lutas. Eu acho, talvez, que o cristão tenha um pouco mais de lutas do que as outras pessoas. Parece que você mata um leão hoje e tem dois já, que estão se levantando pra você amanhã, entendeu?” (Vitória)

"Eu não sei se era o mal, o próprio diabo que estava tentando me atacar de todas as maneiras, porque ele viu que eu estava me libertando na igreja, e ele usava aquilo para me atingir. E se ele tentou, ele conseguiu, porque nossa... eu sofri muito." (Simone)

Deve-se notar também que, embora a IURD ofereça ao público sessōes de descarrego e reuniōes de "cura $e$ libertação", em nenhuma das entrevistas estabeleceu-se a relação entre doença e possessão demoníaca. De acordo com os discursos, a doença é resultado do mal agindo indiretamente na vida do fiel, mas não diretamente no fiel. Rituais de libertação e práticas de exorcismo foram presenciados nas reuniões da igreja, mas ocorreram em uma quantidade pequena de fiéis (em relação ao número total de frequentadores), o que nos faz conjecturar que diminuiu a ênfase dada à expulsão dos demônios, comparando-se ao que foi levantado por outros pesquisadores na década de 1990 (Gomes, 1994; Mariano, 2010).

A possessão demoníaca e a grande ênfase no exorcismo durante os cultos eram elementos que diferenciavam a Universal de outras igrejas, caracterizando-a como pertencente à terceira onda pentecostal (Freston, 1994). Levando-se em conta que não apareceu, nas declarações das colaboradoras, representações da cura como libertação e expulsão dos demônios, e que ainda existem reuniōes reservadas às práticas exorcistas, podemos concluir que esse elemento simbólico não encontra familiaridade entre as fiéis entrevistadas. Ainda assim, acreditase que a doença é causada pelo mal, o que é suficiente para justificar sua não aceitação e a certeza de que a cura será obtida com a colaboração de Deus.

\subsection{Meritocracia e pseudoautonomia}

A igreja surge, tanto no discurso oficial quanto nos depoimentos das entrevistadas, como mera facilitadora dos processos de cura divina. A responsabilidade de eliminar a doença é do próprio fiel: "Quem está por trás disso é o diabo, mas cabe a você mudar essa situação com a palavra de Deus" (Macedo, 2011, p. 331). A jornada pela restauração da saúde é uma questão de mérito, capacidade e competência. Só estão em condições de receber a cura divina aqueles que doam voluntariamente ofertas financeiras. Esse discurso meritocrático parece conceder autonomia aos membros da igreja e atribuir-lhes a tarefa de materializar a cura. 
Aparentemente, qualquer um poderia ser curado, bastando para isso "ter fé" e "buscar a Deus". É em meio a tal subjetividade que os bens simbólicos oferecidos pela igreja surgem como um método inovador e exclusivo para obtenção da cura. Conforme define qual é a fé válida (a fé "sobrenatural", "exercitada", "prática", "inteligente") e qual a maneira correta de se buscar a Deus, a igreja assume novamente o controle dos mecanismos de fé. Essa pseudoautonomia dos membros da igreja pode revelar-se perversa, já que dá margem para que o crente seja responsabilizado pelo fracasso na luta contra a doença.

Já os "louros da vitória" têm destino certo. Campos (1997) explica que Edir Macedo costuma "atrelar o sucesso da dramatização nunca ao ator ou a si próprio, mas ao enredo implícito, do qual a sua igreja detém honrosa mediação simbólica” (p. 99). Esse sucesso não é atrelado explicitamente à igreja, como conta Simone, mas a Deus (ao "Deus vivo", exclusivo da Universal):

O bispo Macedo é uma das pessoas que abominam até a palavra 'religiāo', porque ele fala que isso só existe pra dividir as pessoas. E aí a pessoa às vezes torna-se religiosa a uma placa de igreja ${ }^{3}$ e não pode. Ele fala que tem pessoas na Universal que adoram a placa da igreja e não pode, elas têm que adorar somente a Cristo, a Deus. (Simone)

Segundo Gomes (1994), a IURD já foi conhecida por ser a "única igreja que, de acordo com os discursos dos seus membros, oferece uma tecnologia religiosa realmente eficaz para o restabelecimento da situação humana ideal" (p. 241, grifo nosso). As entrevistas apresentam afirmaçōes contraditórias nesse sentido. Ao mesmo tempo que afirmam a importância da Universal para capacitar o fiel a realizar e desenvolver atos de fé, tratam a igreja como se fosse desnecessária e dispensável:

"Não é a placa que vai salvar. Se tiver que entrar na Igreja Católica, dobrar seu joelho e falar ali com Deus, você fala. Deus vai te responder ali. Mas você tem que saber a maneira que você vai falar com Deus." (Joana, grifo nosso)

"Na verdade, não é a Universal, é a sua fé; lá eles ensinam a exercitar essa fé. Eu falei: 'eu corro lá porque meu problema vai resolver." (Vitória)

Segundo os discursos das colaboradoras, o caráter grupal da experiência religiosa no templo aparentemente não faz parte do processo de cura. A cura divina é narrada como uma experiência individual que ocorre entre o fiel e Deus. Até mesmo o pastor aparece como uma figura secundária. De fato, a busca

\footnotetext{
"Placa de igreja" é uma expressão utilizada no meio evangélico para se referir às diferentes denominações.
} 
pela cura divina é um processo individual, mas não autônomo, porque conta fundamentalmente com a mediação institucional, já que há total vinculação entre o fenômeno da cura e os rituais da igreja. O monopólio dos meios acaba por fidelizar o fiel, mesmo que ele já domine os métodos. Como ressalta Vitória, "Eles ensinam você a pescar, eles não te dão o peixe". Podemos acrescentar que somente é possível pescar da maneira que eles ensinam dentro do lago da Universal.

\subsection{O dízimo e as representações sociais da cura divina}

Segundo Edir Macedo, os membros da igreja adquirem o direito à bênção quando entregam seus dízimos a Deus como prova de fé. Embora esse ensinamento seja exaustivamente apresentado nos escritos do bispo, surpreendentemente foi encontrado um cenário bem diferente retratado pelas fiéis.

Nenhuma das entrevistadas associou a cura divina aos dízimos e ofertas, o que é digno de nota, dado que o discurso oficial da igreja defende que a fé se manifesta e se concretiza por meio dos dízimos e ofertas. Também não relacionaram tão diretamente os dízimos e o direito à bênção, denotando que não o compreendem como um "investimento" (Freston, 1994; Macedo, 2011), embora essa fórmula apareça muitas vezes nos livros do bispo Macedo. A relação entre dízimo e cura é representada pelas colaboradoras de modo significativamente diferente do discurso institucional e revela a tentativa de manter a separação entre o mundo espiritual e o mundo secular.

Uma única colaboradora (Vitória) fez menção à tese do direito adquirido, argumentando que os fiéis devem viver com prosperidade e abundância, visto que são "filhos do dono do ouro e da prata". Mesmo assim, não fez nenhuma associação desse direito às contribuições financeiras. O preconceito sentido pelos fiéis (frequentemente tratados como sujeitos alienados, enganados e explorados financeiramente) pode ser a causa dessa dificuldade de ancoragem e objetivação de um assunto tão complexo e desconfortável.

O desconforto relacionado à articulação entre dízimo e direito gera a necessidade de justificar e explicar os procedimentos institucionais de modo a evitar interpretações que confirmem a tese da "compra" da bênção. As explicações são formuladas seja por razôes de consciência, seja para minimizar o preconceito de quem não pertence à igreja. As entrevistadas contaram que a discriminação aos fiéis e à igreja provém da fama de "mercenária" que a Universal conquistou ao longo de sua existência. 
Em todas as entrevistas, as mulheres espontaneamente resolveram esclarecer a questão dos dízimos em dois aspectos:

a) o dízimo é uma contribuição voluntária. Tal afirmação surgiu de forma semelhante em todos os discursos: "ninguém te obriga", "ninguém põe a mão no seu bolso", "ninguém pega da tua bolsa";

b) o dízimo é a manifestação da gratidão a Deus ou da generosidade e compaixão com outros, uma vez que garante a manutenção da estrutura da igreja, necessária para que outras pessoas possam ser abençoadas por meio dela:

Eu acho que, se eu tivesse grana, eu acho que eu doaria muito mais, acho que seria muito pouco perto de tudo que eu recebi dele, sabe? [...] Não preciso dos meus $10 \%$, quem precisa realmente são outras pessoas que estão sofrendo como eu sofri e essas pessoas precisam que tenha uma igreja próxima a ela $[$ sic]. (Vitória)

\section{CONSIDERAÇŌES FINAIS}

As representaçōes sociais da cura divina, reveladas nos discursos das entrevistadas, mostram certa adaptação do discurso da igreja ao universo simbólico dos fiéis, assim como certa modificação do sistema de referência de cada indivíduo para incorporar os sentidos institucionais. No processo de ancoragem, algumas ideias novas não são articuladas ao repertório simbólico dos membros da igreja, enquanto outras sofrem transformaçōes e adaptações para se tornarem mais familiares e, portanto, mais aceitáveis. Outras, ainda, são reproduzidas de maneira fidedigna, parecendo em alguns momentos uma simples repetição do discurso oficial.

A questão da cura divina como um direito do fiel é um elemento simbólico que as participantes da pesquisa não reproduziram em seus depoimentos. Argumentaram que o crente iurdiano exige a cura divina por meio da revolta da fé, não porque entenda que tenha direito à cura, mas porque a revolta contra a doença representa a tomada de posição do cristão na luta contra o mal. Nesse sentido, a revolta é mais uma confissão de fé do que a exigência de um direito adquirido por meio do dízimo.

As representações do dízimo no que diz respeito à cura divina mostraram-se, de igual modo, diferentes do discurso do bispo Macedo: enquanto ele ensina que o dízimo é um investimento, as entrevistadas o veem como uma demonstração de gratidão a Deus pelas bênçãos recebidas. Há certa resistência e desconforto por parte das colaboradoras em associar as questóes espirituais às financeiras, 
ao passo que não há nenhum constrangimento por parte da igreja em fazer tal associação.

A medicina se apresenta não mais como uma concorrente no território da saúde e, conforme atesta a existência da doença e a posterior ocorrência da cura, surge como legitimadora da cura divina. O saber médico, antes temido e rejeitado pela igreja, passa a ser aliado da cosmovisão iurdiana; não há mais competição pelo monopólio do saber referente às patologias e aos tratamentos, mas um comensalismo em que o discurso religioso preenche as lacunas do discurso médico. A medicina é concebida pelos fiéis como útil, mas insuficiente, e é nessa insuficiência do saber e do poder médicos que o discurso religioso encontra espaço, o que nos faz inferir que a insuficiência da medicina em promover saúde pode gerar demandas de curas espirituais.

As declarações das entrevistadas também revelaram a presença de princípios neoliberais nas representaçôes sociais da cura divina, entendida como uma tarefa individual e meritocrática, ignorando a dimensão coletiva das práticas religiosas. A adequação da igreja às demandas de um público que age como consumidor também se faz notar na constante inovação dos bens simbólicos oferecidos pela instituição (campanhas, propósitos e objetos). A própria imagem que a igreja oferece dela mesma, não mais como a única que cura e liberta, difunde a ideia de liberdade individual para fazer escolhas, produzindo nos fiéis uma falsa sensação de autonomia. 


\section{REFERENNCIAS}

Bittencourt Filho, J. (1994). Remédio amargo. In A. Antoniazzi, (Org.), Nem anjos nem demônios: interpretaçôes sociológicas do pentecostalismo. (pp. 24-34). Petrópolis: Vozes.

Bosi, E. (2003). O tempo vivo da memória: ensaios de Psicologia social. São Paulo: Ateliê.

Campos, L. S. (1997). Teatro, templo e mercado: organização e marketing de um empreendimento neopentecostal. Petrópolis: Vozes.

Freston, P. (1994). Breve história do pentecostalismo brasileiro. In A. Antoniazzi, (Org.), Nem anjos nem demônios: interpretaçôes sociológicas do pentecostalismo. (pp. 67-159). Petrópolis: Vozes.

Gil, A. C. (1999). Métodos e técnicas de pesquisa social. São Paulo: Atlas.

Gomes, W. (1994). Nem anjos nem demônios. In A. Antoniazzi, (Org.), Nem anjos nem demônios: interpretaçôes sociológicas do pentecostalismo. (pp. 225-269). Petrópolis: Vozes.

Macedo, E. (2006). Orixás, caboclos e guias: deuses ou demônios? Rio de Janeiro: Universal.

Macedo, E. (2011). Mensagens do bispo Macedo: compiladas entre 2007 e 2010. Rio de Janeiro: Unipro.

Mariano, R. (2010). Neopentecostais: sociologia do novo pentecostalismo no Brasil. (3a ed.). São Paulo: Loyola.

Moscovici, S. (1961). La psychanalyse: son image et son public. Revue française de sociologie, 1961, 2-4. pp. 328-330.

Moscovici, S. (2003). Representaçôes sociais: investigaçôes em Psicologia social. Petrópolis: Vozes.

Oro, A. P. (2001). Neopentecostalismo: dinheiro e magia. Revista de Antropologia Ilha, 3(1), 71-85.

Romeiro, P. (2007). Supercrentes. São Paulo: Mundo Cristão.

Sá, C. P. (1995). Representaçôes sociais: o conceito e o estudo atual da teoria. In M. J. P. (Org.), O conhecimento no cotidiano: as representaçôes sociais na 
perspectiva da Psicologia social. (pp. 19-45). São Paulo: Brasiliense.

Thompson, J. B. (2000). Ideologia e cultura moderna: teoria social critica na era dos meios de comunicação de massa. Petrópolis: Vozes. 